\title{
Permanent magnets for water-scale prevention
}

\author{
Lipus, L.C. ${ }^{\mathrm{a},{ }^{*}}$, Hamler, A. ${ }^{\mathrm{b}}$, Ban, I. ${ }^{\mathrm{c}}$, Acko, ${ }^{\text {B. }}{ }^{\mathrm{a}}$ \\ ${ }^{a}$ Faculty of Mechanical Engineering, University of Maribor, Maribor, Slovenia \\ ${ }^{\mathrm{b}}$ Faculty of Electrical Engineering and Computer Science, University of Maribor, Maribor, Slovenia \\ ${ }^{c}$ Faculty of Chemistry and Chemical Engineering, University of Maribor, Maribor, Slovenia
}

\section{A B S T R A C T}

Anti-scale magnetic treatment (AMT) is discussed with the emphasis on the construction of magnetic devices and the mechanism of AMT influence on scale formation. Two field cases are reported of mineral-fouling reduction during water heating by using permanent magnets. Instead of hard encrustation on the heated surfaces a powdery deposit was formed because of modified crystal morphology (observed by X-ray powder diffractometry and scanning-electron microscopy). In order to find a proper design for magnets regarding the influencing parameters (a magnetic-field distribution with alternating lines orthogonal to the water-flow and minimal density peaks $0.2 \mathrm{~T}$ ), cost-effective for actual water-flow capacities, several models with $\mathrm{NdFeB}$ magnets were simulated by the finite-element method using the OPERA 15R1 computational program. Two optimized models are presented for moderate capacities: a model with a rectangular gap (a two-row set of rectangular magnets) for capacities from $0.5 \mathrm{~m}^{3} / \mathrm{h}$ to $3 \mathrm{~m}^{3} / \mathrm{h}$, and a model with annular gap (annular magnets on a pipe and disk magnets within a cylindrical kernel) for $3.5 \mathrm{~m}^{3} / \mathrm{h}$ to $5.5 \mathrm{~m}^{3} / \mathrm{h}$

(c) 2015 PEI, University of Maribor. All rights reserved.
\end{abstract}

\section{ARTICLE INFO}

Keywords:

Scale control

Calcium carbonate

Magnetic water treatment

Permanent magnets

Modelling

*Corresponding author:

lucija.lipus@um.si

(Lipus, L.C.)

Article history:

Received 30 January 2015

Revised 16 November 2015

Accepted 20 November 2015 


\title{
Trajni magneti za preprečevanje vodnega kamna
}

\author{
Lipus, L.C. ${ }^{\mathrm{a},{ }^{*}}$, Hamler, A. ${ }^{\mathrm{b}}$, Ban, I. ${ }^{\mathrm{c}}$, Acko, ${ }^{\text {B. }}{ }^{\mathrm{a}}$ \\ ${ }^{a}$ Faculty of Mechanical Engineering, University of Maribor, Maribor, Slovenia \\ ${ }^{\mathrm{b}}$ Faculty of Electrical Engineering and Computer Science, University of Maribor, Maribor, Slovenia \\ ${ }^{c}$ Faculty of Chemistry and Chemical Engineering, University of Maribor, Maribor, Slovenia
}

\begin{abstract}
POVZETEK
Prispevek obravnava magnetno obdelavo za preprečevanje vodnega kamna; poudarek je na konstrukciji magnetne naprave in mehanizmu vpliva obdelave na tvorbo oblog. Poroča o dveh primerih zmanjšanja oblog med segrevanjem vode $\mathrm{z}$ uporabo magnetov: namesto trde obloge na grelni površinah se je tvorila prašnata prevleka kot posledica sprememb v obliki kristalizacije (opaženih z rentgenskim praškovnim difraktometrom in skenirnim elektronskim mikroskopom). Za postavitev ustreznega modela magnetne naprave, rentabilne za realne pretoke vode, so bili - upoštevajoč vplivne parametre (tj. porazdelitev magnetnega polja z izmeničnimi silnicami pravokotnimi na vodni tok in vrhovi gostote magnetnega polja minimalno $0.2 \mathrm{~T}$ ) - simulirani razni modeli magnetov $\mathrm{NdFeB} \mathrm{z}$ metodo končnih elementov in $\mathrm{z}$ uporabo računalniškega programa OPERA 15R1. V delu sta predstavljena dva optimalna modela: vzporedni niz pravokotnih magnetov za zmerne vrednosti pretokov $0.5 \mathrm{~m} 3 / \mathrm{h}$ do 3 $\mathrm{m} 3 / \mathrm{h}$ in model s prstanasto režo (niz prstanastih magnetov na cevi in diskastih magnetov znotraj cilindričnega jedra) za večje pretoke, 3.5 do $5.5 \mathrm{~m} 3 / \mathrm{h}$.
\end{abstract}

\section{PODATKI O ČLANKU}

Ključne besede:

Preprečevanje vodnega kamna

Kalcijev karbonat

Magnetna obdelava vode

Trajni magneti

Modeliranje

*Kontaktna oseba:

lucija.lipus@um.si

(Lipus, L.C.)

Zgodovina članka:

Prejet 30. januarja 2015

Popravljen 16. novembra 2015

Sprejet 20. novembra 2015 


\section{References}

[1] Alimi, F.; Tlili, M.M., Ben Amor, M., Maurin, G., Gabrielli, C. (2009). Effect of magnetic water treatment on calcium carbonate precipitation: Influence of the pipe material, Chemical Engineering and Processing, Vol. 48, No. 8, 1327-1332, doi: 10.1016/j.cep.2009.06.008.

[2] Alimi, F., Boubakri, A., Tlili, M.M., Ben Amor, M. (2014). A comprehensive factorial design study of variables affecting $\mathrm{CaCO}_{3}$ scaling under magnetic water treatment, Water Science and Technology, Vol. 70 No. 8, 1355-1362.

[3] Chang, M.C., Tai, C.Y. (2010). Effect of the magnetic field on the growth rate of aragonite and the precipitation of $\mathrm{CaCO}_{3}$, Chemical Engineering Journal, Vol. 164, No. 1, 1-9, doi: 10.1016/j.cej.2010.07.018.

[4] Stuyven, B., Vanbutsele, G., Nuyens, J., Vermant, J., Martens, J.A. (2009). Natural suspended particle fragmentation in magnetic scale prevention device, Chemical Engineering Science, Vol. 64, No. 8, 1904-1906, doi: 10.1016/j.ces.2008.12.022.

[5] Lipus, L.C., Dobersek, D. (2007). Influence of magnetic field on the aragonite precipitation, Chemical Engineering Science, Vol. 62, No. 7, 2089-2095, doi: 10.1016/j.ces.2006.12.051.

[6] Lee, S.H., Cho, Y.I. (2002). Velocity effect on electronic-antifouling technology to mitigate mineral fouling in enhanced-tube heat exchanger, International Journal of Heat and Mass Transfer, Vol. 45, No. 20, 4163-4174, doi: 10.1016/S0017-9310(02)00104-7.

[7] Xing, X.K. (2008). Research on the electromagnetic anti-fouling technology for heat transfer enhancement, $A p$ plied Thermal Engineering, Vol. 28, No. 8-9, 889-894, doi: 10.1016/j.applthermaleng.2007.07.006.

[8] Shahryari, A., Pakshir, M. (2008). Influence of a modulated electromagnetic field on fouling in a double-pipe heat exchanger, Journal of Materials Processing Technology, Vol. 203, No. 1-3, 389-395, doi: 10.1016/j.jmatprotec. 2007.10.048.

[9] Lipus, L.C., Ačko, B., Hamler, A. (2011). Electromagnets for high-flow water processing, Chemical Engineering and Processing, Vol. 50, No. 9, 952-958, doi: 10.1016/i.cep.2011.07.004.

[10] Tijing, L.D., Kim, H.Y., Lee, D.H., Kim, C.S., Cho, Y.I. (2010). Physical water treatment using RF electric fields for the mitigation of $\mathrm{CaCO}_{3}$ fouling in cooling water, International Journal of Heat and Mass Transfer, Vol. 53, No. 7-8, 1426-1437, doi: 10.1016/j.ijheatmasstransfer.2009.12.009.

[11] Hasson, D., Sidorenko, G., Semiat, R. (2011). Low electrode area electrochemical scale removal system, Desalination and Water Treatment, Vol. 31, No. 1-3, 35-41, doi: 10.5004/dwt.2011.2389.

[12] Al Nasser, W.N., Pitt, K., Hounslow, M.J., Salman, A.D. (2013). Monitoring of aggregation and scaling of calcium carbonate in the presence of ultrasound irradiation using focused beam reflectance measurement, Powder Technology, Vol. 238, 151-160, doi: 10.1016/j.powtec.2012.03.021.

[13] Baker, J.S., Judd, S.J. (1996). Magnetic amelioration of scale formation, Water Research, Vol. 30, No. 2, 247-260, doi: $10.1016 / 0043-1354(95) 00184-0$.

[14] Tai, C.Y., Chang, M.C., Liu, C.C., Wang, S.S.S. (2014). Growth of calcite seeds in a magnetized environment, Journal of Crystal Growth, Vol. 389, 5-11, doi: 10.1016/0043-1354(95)00184-0.

[15] Ravnik, J., Hribersek, M., Vogel, F., Steinmann, P. (2014). Numerical simulation of particle movement in cellular flows under the influence of magnetic forces, International Journal of Simulation Modelling, Vol. 13, No. 3, 300311, doi: $10.2507 /$ IJSIMM13(3)4.268.

[16] Oshitani, J., Yamada, D., Miyahara, M., Higashitani, K (1999). Magnetic effect on ion-exchange kinetics, Journal of Colloid and Interface Science, Vol. 210, No. 1, 1-7, doi: 10.1006/jcis.1998.5952.

[17] Madsen, H.E.L. (2007). Theory of electrolyte crystallization in magnetic field, Journal of Crystal Growth, Vol. 305, No. 1, 271-277, doi: 10.1016/j.jcrysgro.2007.04.023.

[18] Lipus, L.C., Krope, J., Crepinsek, L. (2001). Dispersion destabilization in magnetic water treatment, Journal of Colloid and Interface Science, Vol. 236, No. 1, 60-66, doi: 10.1006/icis.2000.7392.

[19] Gabrielli, C., Jaouhari, R., Maurin, G., Keddam, M. (2001). Magnetic water treatment for scale prevention, Water Research, Vol. 35, No. 13, 3249-3259, doi: 10.1016/S0043-1354(01)00010-0.

[20] Coey, J.M.D., Cass, S. (2000). Magnetic water treatment, Journal of Magnetism and Magnetic Materials, Vol. 209, No. 1-3, 71-74, doi: 10.1016/S0304-8853(99)00648-4.

[21] Tebenihin, E.F., Gusev, B.T. (1970). Obrabotka vody magnitnym polem v teploenergetike, Energija, Moscow.

[22] Klassen, V.I. (1982). Omagnicivanie vodnyh system [Magnetization of Water Systems], Moscow: Khimiya], Himija, Moskva.

[23] Szkatula, A., Balanda, M., Kopeć, M. (2002). Magnetic treatment of industrial water. Silica activation, European Physical Journal - Applied Physics, Vol. 18, No. 1, 41-49, doi: 10.1051/epjap:2002025.

[24] Grutch, J.E., McClintock, J.W. (1984) Corrosion and deposit control in alkaline cooling water using magnetic water treatment at AMOCO's largest refinery, Corrosion, Vol. 84, No. 330, 1-26.

[25] Grimes, S.M. (1988). Magnetic field effect on crystals, Tube International, Vol. (March).

[26] Darvill, M. (1993). Magnetic water treatment, Water and Waste Treatment, Vol. 40 (July).

[27] Tye, A. (1993). The magnetic treatment of water to prevent scaling, Resource, Vol. 1, 25-26.

[28] Higashitani, K., Oshitani, J. (1998). Magnetic effects on thickness of adsorbed layer in aqueous solutions evaluated directly by Atomic Force Microscope, Journal of Colloid and Interface Science, Vol. 204, No. 2, 363-368, doi: 10.1006/jcis.1998.5590.

[29] Ohata, R., Tomita, N., Ikada, Y. (2004). Effect of a static magnetic field on ion transport in a cellulose membrane, Journal of Colloid and Interface Science, Vol. 270, No. 2, 413-416, doi: 10.1016/i.jcis.2003.09.035.

[30] Zakharov, A.G., Maximov, A.I., Koksharov, S.A. (1996). The properties of physical effect applications under textile material treatment, In: Proceedings of the 17th IFVTCC Congress, Vienna, Austria, 173-176. 
[31] Lipus, L.C., Acko, B., Neral, B. (2013). Influence of magnetic water treatment on fabrics' characteristics, Journal of Cleaner Production, Vol. 52, 374-379, doi: 10.1016/i.jclepro.2013.03.014.

[32] Bozic, M., Lipus, L.C., Kokol, V. (2008). Magnetic field effects on redox potential of reduction and oxidation agents, Croatica Chemica Acta, Vol. 81, No. 3, 413-421.

[33] Liu, Y., Jia, S., Ran, J., Wu, S. (2010). Effects of static magnetic field on activity and stability of immobilized $\alpha-$ amylase in chitosan bead, Catalysis Communications, Vol. 11, No. 5, 364-367, doi: 10.1016/i.catcom.2009.11.002.

[34] Govindasamy, P., Dhandapani, S. (2007). Experimental investigation on the effect of magnetic flux to reduce emissions and improve combustion performance in a two-stroke, catalytic-coated, spark-ignition engine, International Journal of Automotive Technology, Vol. 8, No. 5, 533-542.

[35] Kozic, V., Hamler, A., Ban, I., Lipus, L.C. (2010). Magnetic water treatment for scale control in heating and alkaline conditions, Desalination and Water Treatment, Vol. 22, No. 1-3, 65-71, doi: 10.5004/dwt.2010.1549.

[36] Edwin Raja Dhas, J., Somasundaram, K. (2013). Modeling and prediction of HAZ using finite element and neural network modeling, Advances in Production Engineering \& Management, Vol. 8, No. 1, 13-24, doi: 10.14743/ apem2013.1.149.

[37] Lipus, L.C., Acko, B., Hamler, A. (2012). Magnetic device simulation modelling and optimisation for scale control, International Journal of Simulation Modelling, Vol. 11, No. 3, 141-149, doi: 10.2507/IJSIMM11(3)3.205. 